Каріне ХАЧАТУРЯН,

Харківського державного автотранспортного коледжу (Харків, Україна) kartinka13210@ukr.net

\title{
СПЕЦИФІКА ПРОСТОРОВО-ЧАСОВОЇ ОРГАНІЗАЦІЇ РОМАНУ ПАНАСА МИРНОГО «ХІБА РЕВУТЬ ВОЛИ, ЯК ЯСЛА ПОВНІ?»
}

\begin{abstract}
У статті простежено категорію часопростору як жанрову ознаку роману Панаса Мирного «Хіба ревуть воли, як ясла повні?». Детальне вивчення цього питання дозволяє зрозуміти природу реалістичної манери письма в українському варіанті. 3'ясовано зміст поняття «хронотоп». Визначено диференціацію понять «простір» $i$ «час», які відносяться до основних категорій філософії, естетики, психології, лінгвістики, мистеитва.

Роман Панаса Мирного «Хіба ревуть воли, як ясла повні?» є підсумком творчих пошуків художника у зображенні народного характеру. Письменник свідомо обирає переломні моменти в житті украӥнського селянства, коли, на його думку, найбільш повно виявляються корінні, нерідко суперечливі риси національного характеру. При иьому головним для автора стає пошук $і$ зображення правди часу, народної точки зору на події та героїв. Ці ідеї зумовлюють своєрідність $і$ иілісність художнього світу роману Панаса Мирного, який вибудовується навколо украӥнського селянина з його буденними турботами і вічним прагненням до гармонії з собою і навколишнім світом.

Час і простір у романі - фактори, які формують життєві иілі героїв, визначають їхні характери, душевні нахили, світогляд. Просторово-часовий континуум у романістиці Панаса Мирного відіграє важливу роль як форма вираження морального начала людської особистості. Тому розглядати художнє значення просторовочасових образів у романі Панаса Мирного «Хіба ревуть воли, як ясла повні?» і проблему взаємодї прекрасного й морального в естетиці Панаса Мирного можна лише у взаємозалежності. Вважаємо, щзо час і простір у структурній організації роману Панаса Мирного є важливими категоріяли жанрового розмежування. Завдяки їм письменник «розсуває» межі, виводить оповідь за рамки біографічного та історичного часу і простору.
\end{abstract}

Ключові слова: часопростір, хронотоп, реальність, пам'ять.

Karine KHACHATURIAN, orcid.org/0000-0003-4131-1836

Teacher

Kharkov State Transportation College

(Kharkiv,Ukraine) kartinka13210@ukr.net

\section{SPECIFICITY OF THE SPATIO-TEMPORAL ORGANIZATION OF THE PANAS MYRNY'S NOVEL "DO OXEN LOW, WHEN MANGERS ARE FULL?"}

The category of timeline as a genre sign of Panas Myrny's novel "Do oxen low, when mangers are full?" is traced in the article. A detailed study of these issues makes possible to understand the nature of the realistic manner of writing in the Ukrainian version. The meaning of the concept of "chronotope" has been clarified. The differentiation of the concepts of "space" and "time" is determined, which belong to the main categories of philosophy, aesthetics, psychology, linguistics, art.

Panas Myrny's novel "Do oxen low, when mangers are full?" is the result of the artist's creative searches in the image of a folk character. The writer meaningfully chooses breaking points in the life of the Ukrainian peasantry, when, in his opinion, indigenous, often contradictory features of a national nature are most fully manifested. With all this, the main thing for the author is the search and depiction of the truth of time, the folk point of view on events and heroes. These ideas determine the originality and integrity of the artistic world of the novel by Panas Myrny, which is built around a Ukrainian peasant with his everyday concerns and eternal aspirations for harmony with himself and the world around him.

Time and space in the novel is a factor that forms the life goals of heroes, determining their characters, mental inclinations, worldview. The space-time continuum in the novelism of Panas Myrny plays an important role as a form of expressing the moral beginning of the human identity. In this regard, it is possible to consider the artistic significance of time-space images in Panas Myrny's novel "Do oxen low, when mangers are full?" interdependently with the problem of the interaction of the beautiful and the moral in the aesthetics of Panas Myrny. In our opinion, the time and space in the structural organization of the novel by Panas Myrny is important in the category of genre distinction. Thus, the writer extends the borders, takes the narration beyond the biographical and historical time and space.

Key words: time-space, chronotope, reality, memory. 
Постановка проблеми. Кардинальним напрямом літературознавчої науки є тенденція щодо розгляду понять художнього часу i простору в творчості окремих письменників. Простір і час як універсальні категорії людського мислення мають велике значення в сучасному літературознавстві, $\epsilon$ характеристиками реального і художнього світів, способом відображення дійсності. Художній час і простір найбільш повно характеризують світовідчуття, поведінку людей певної епохи, слугують конструктивними принципами побудови літературного твору, а також «мовою» його розуміння. У літературознавстві ці поняття $€$ одними із найважливіших характеристик твору як художньої моделі світу автора.

У літературознавчу практику поняття «хронотоп» вперше було введено російським філософом М. Бахтіним. Він позначає хронотоп як взаємозв'язок часових i просторових координат художнього тексту: «Прикмети часу розкриваються у просторі, а простір осмислюється і вимірюється часом. Цим пересіченням рядів i злиттям прикмет характеризується художній хронотоп» (Бахтин, 1975: 234). У художньому хронотопі М. Бахтін виокремлює важливу і найбільш значущу його частину - художній час, що позначилося і на визначенні поняття (хронотоп із грецької означає «часопростір»): «Час тут згущується, ущільнюється, стає художньо-зримим; простір інтенсифікується, втягується в рух часу, сюжету, історії» (Бахтин, 1975: 234). Науковець розглядає хронотоп як формально-змістовну категорію літератури. Він говорить про те, що в літературно-художньому хронотопі має місце злиття просторових і часових прикмет в осмисленому i конкретному цілому, при цьому важливою є символіка хронотопних образів.

Як зазначає Ю. Лотман, «художній простір не зводиться до простого відтворення тих чи інших локальних характеристик реального ландшафту, він $\epsilon$ «моделлю світу і конкретного автора», континуумом, у якому розміщуються персонажі і відбувається дія» (Лотман, 1992: 418).

Актуальність цієї розвідки зумовлюється необхідністю детального аналізу часово-просторових координат художнього твору; потребою в дослідженні дій і думок автора та його героїв у потоці часу і в просторі, що сприятиме глибшому розумінню світогляду письменника та усвідомленню справжньої цінності його творчості.

Аналіз досліджень. Художній час і простір у літературному творі стає предметом пильної уваги М. Бахтіна, В. Бірона, Б. Кормана,
В. Халізева, Д. Ліхачова, А. Еселнек, А. Мостепаненко, Р. Зобова, В. Жирмунского, А. Гуревича, Н. Фалікової, Р. Барта, В. Віноградова, С. Арутюнова, Е. Мелетинського, В. Проппа, А. Лосєва, В. Заманського, Т. Прохорової, В. Шкловського.

Дослідники визнавали, що художній час і простір - найважливіші категорії, які організовують унікальний світ твору. Час і простір відображаються в літературному творі відповідно до уявлень автора, його задуму та концепції.

Поряд із визначенням значущості категорій часу і простору в літературі велика увага приділялася їх вивченню 3 точки зору історичної поетики. Дослідники стверджували, що час і простір у художньому творі цілком залежні не тільки від індивідуальної авторської картини світу, але й від літературного напряму, в рамках якого творить художник (Д. Ліхачев, В. Пропп, М. СтеблінКаменський, М. Бахтін, І. Роднянський).

Дослідження показують, що зміна культурної ідеології кінця ХХ століття, а разом із нею і світовідчуття людини, перетворилася у глобальну зміну концепції часопростору. Попередня ідея про час, подібний лінії, спрямованій чітко з минулого в майбутнє, зійшла нанівець. Час перестає розумітися як впорядкований континуум. Спостерігається переважання часу справжнього над минулим і майбутнім. На перший план виходить категорія простору з її різноманіттям форм.

Художній час і простір, засновані на реальності, у романістиці письменника мають принципове значення у зв'язку з соціокультурними перетвореннями дійсності кінця XIX - початку XX століття. В українській літературі початку XX століття відбуваються значні зміни: з'явилася нова культурологічна орієнтація, що свідчить про появу нових жанрів, посилення інтересу до української літератури.

Мета статті - визначити хронотопічні особливості роману Панаса Мирного «Хіба ревуть воли, як ясла повні?».

Виклад основного матеріалу. Для українського народу ситуація кінця XIX - початку XX століття була унікальною, оскільки відбулися зміни у традиційній системі мислення. Змінюється погляд на людину та іiї місце у світі, відбувається розширення художнього простору і часу. Згадане соціокультурне явище трансформується у творчості Панаса Мирного. Письменник зміг прийти до бачення прихованих основоположних законів життя, втілення яких у літературі стало основою для унікальності й неповторності його творчого доробку. Уважно спостерігаючи за довкіллям, ана- 
лізуючи вчинки людей, показуючи полюсні точки зору, письменник прийшов до відкриття нескінченного лабіринту - складного багатства життя та його устрою.

Романістика Панаса Мирного відобразила інтенсивні ідейно-естетичні пошуки письменника і стала свідченням про багатий і цікавий розвиток української літератури кінця XIX - початку XX століття. Твір Панаса Мирного «Хіба ревуть воли, як ясла повні?» - це роман про час і пам'ять, втрату і біль. У понятті часу твору вживаються різні часові сполучення, в ньому зберігається час автора, час книги, час реципієнта. У мистецтві відображено те, як людина завжди намагається подолати якісь перешкоди на своєму життєвому шляху, зробити щось таке, що збереже про неї добру пам'ять. Тому і тема пам'яті трактується як одна $з$ головних. Пам'ять активна. Саме вона керує часом, може заміняти теперішнє минулим, примушує постійно оглядатися на нього. Пам'ять $є$ символічним відтворенням минулого, його поверненням, відтворенням у теперішньому. Онтологічні та екзистенційні потреби в пам'яті для людини полягають у протистоянні нищівній дії часу.

Перед нами постають думки Мотрі: «У пам’яті прокинулись ті давні часи, як на чужім полі на людей жила, зі снопа заробляла, як п'ять снопів людям нажни, собі шостий одверни, як за цілий довгий літній день од світової зорі до вечірньої, спини не розгинаючи, тільки двадцять снопів і заробила» (Мирний, 1968: 102).

Ось інший епізод:

«- Який небіж?... Звідкіля?

- Кажу ж із Дону! - одмовив Чіпка.

- 3 Дону? - якось боязко запитала Мотря та й опустилася на лаву» (Мирний, 1968: 100).

Одне невеличке слівце «Дін», як молотком, ударило іiї в голову. ... Пам'ять у неї зразу прокинулась і нагадала, що вже раз прийшла була про неї лиха година 3 Дону, котра перевернула все іiі життя та й кинула бідувати на старість. ... «Чи не нова, бува, прийшла знову з того проклятого Дону?» - думала Мотря, глядячи на сина, хоч нічого й не бачила, бо у віччю в неї почорніло, затуманилось» (Мирний, 1968: 100).

Минуле і теперішне у романі тісно переплітаються. Панас Мирний написав твір у роки загострення другої революційної ситуації у державі, віддзеркаливши основні суперечності сумної дійсності у всій їх гостроті. Вираження епохи в романі насамперед опирається на життєву достовірність явищ, процесів, фактів (значна частина має документальне підтвердження); на реальність багатьох прототипів (Чіпки, панів
Польських, Шведових); на хронікальність (повну відповідність романного і реального часу) розвитку сюжетних ліній. Автор використовує взаємодію просторово-часової рамки 3 хронотопом автобіографії героя для показу роботи пам'яті і вираження своїх поглядів на час. Автобіографічна форма, яка складається із вкладень просторово-часових рівнів, дозволяє письменнику створити оповідну структуру, побудовану відповідно до його уявлень про властивості часу.

Аналізуючи організацію художнього простору в романі, варто звернути увагу на «вертикалізм» романного простору, який складається із двох сфер, повернутих одна до одної (минулого і сьогодення), розділених водною поверхнею. В романі не раз зустрічається вода, яка виконує роль своєрідного водорозділу. «Велике місто зі своїми церквами високими, зі своїми палацами довгими та широкими, 3 кам'яними крамницями розкинулось на невеличкім згірку. Внизу, посеред города (міста), текла річка - широка й глибока; багато по ній снувало барок, плотів, пароходів; коло річки й на вулицях - гармидер, крик, тіснота, як на ярмарку» (Мирний, 1968: 83).

«Річ Чіпчина, як вода, ринула. Грицько з Христею слухали та ззиралися, а Христя коли-не-коли зітхала тихо та глибоко». Автор показав етап занапащення Чіпчиної долі: «Полилася горілка, як вода. Він дудлив іï нахильці; випив 3 півкварти й не чув, щоб хоч запекла або вдарила в голову» (Мирний, 1968: 118). Герой Панаса Мирного то занурюється на дно - на дно життя, коли зникає надія на порятунок і з'являється відчай і безвихідь (землю відібрали, до земства не обрали), то переміщується вгору (зустріч із Галею, повернення до нормального життя).

Письменник поділяє простір на:

- простір 1 (П1) - замкнутий, обмежений, побутовий. Це той звичний простір, у якому формується Чіпка як особистість - надзвичайно чуйний хлопчик. У творі хата просторово правильно оформлена: стеля, підлога, вікна, двері: «Хата хоч старенька, та чепурна, біла, видно, що біля неї ходили хазяйські руки; двір виметений, чистий; огорожа ціла, хоч і низенька, а ворота дощані-хрещаті». Проте героєві у звичному для нього колі стає затісно, й хлопчик розмикає добре досліджений ним простір, розширює його (йде до діда Уласа служити). Світ за межами звичного простору виявляється зовсім іншим, але тільки 3 часом головний герой дізнається, що в ньому далеко не все так гармонійно й безконфліктно, як здається на перший погляд, що разом із розширенням простору збільшуються й «гріхи» та «кари»; 
- простір 2 (П2) - відкритий, безмежний, природний. «Спустившись у долину, повернув із курного шляху на обніжок і пішов поміж зеленими житами. Ось підійшов до однієї ниви, нахилився, вирвав при самім корені пучок жита, глянув на його, далі глянув на ниву, і лице засвітилося одрадою» (Мирний, 1968: 2). Це було саме те місце, в якому герой зустрівся зі своєю коханою.

Світ героя наповнений улюбленими предметами, кожен із яких має певну цінність. Цей світ автор конкретизував (жито, нива): «Повертівши в руках вирване жито, він скинув очима на другий бік межі; знову глянув на свою ниву, наче рівняв дві ниви між собою, і промовив уголос: «Бач, на нашому поліжито краще, ніжу дядька Кабанця: моє таке густе та гонке, а в його-ледве од землі одлізло: низеньке, жовте, засмоктане» (Мирний, 1968: 53).

Матеріальним втіленням художнього простору може бути пейзаж. Пейзаж - це словесна картина зовнішнього світу щодо людини простору і об'єктів, які їй належать. Пейзаж може виконувати роль декорації, фону, бути засобом вираження авторської позиції. Пейзажі роману «Хіба ревуть воли, як ясла повні?» сповнені одухотвореного ліризму, передають відтінки найглибших внутрішніх переживань, підтверджують думки і почуття героїв роману. Коли Чіпка вперше побачив Галю, то «вона підбирала квітки та зв'язувала їх у невеличкі пучечки одномасних кольорів. Навкруги тихо, гарно, зелено; тільки буйні жита стиха шурчали довгими колосками, мов розмовляли 3 собою; од квіток пахощі разом 3 повітрям втягалися грудьми і легко й мило було дихати» (Мирний, 1968: 37).

Розпочинається роман описом весни після зими. Пейзаж характеризується суб'єктивною емоційністю авторського бачення і $\epsilon$ широкою узагальненою картиною пробудження землі, усього живого після холодної зими. У цій картині відчувається прагнення до конкретизації, окреслюється масштаб і співрозмірність розгортання подій, формується і починає відігравати важливу роль траєкторія авторського погляду. Спочатку погляд автора фіксує таїнство весняного дня, зародження нового періоду, але поступово він невблаганно знижується. У той момент, коли його погляд торкається землі, у монументальний світ природи опосередковано вривається людське начало. Широта, осяжність погляду ще зберігається, та монументальність втрачається, що супроводжується зміною відчуття часу.

Умовно цей фрагмент складається із сонячного весняного небесного дня і земного дня: перший передає не лише часову конкретику, плин часу, а й один із моментів одвічної космічної сталості, яка існує у формі циклу, безкінечної повторюваності. Поступово весняні метаморфози втрачають плавність, усталену послідовність, змінюється і характер руху, який стає більш дієвим, інтенсивним, у певному розумінні одночасно-хаотичним. Весняний день руйнує величну гармонію небесного, настає конкретний день, час космічний втілюється в земному, монументальна циклічність поступається профанній лінійності.

Ці смислові зміни зумовлені змінами траєкторії погляду автора. Спочатку вона була вертикальною: небо - земля, сонце - все живе на землі. Досягши тверді, траєкторія погляду автора стає горизонтальною. Поступово в горизонтальній площині він виокремлює людину, яка спочатку постає в загальному потоці живого, але досить швидко стає одиницею пануючою, оскільки земний відлік руху і часу насамперед пов'язаний із нею. Невипадково саме в той момент, коли погляд автора викоремлює людину, він ніби зупиняється, концентруючись в одній точці.

3'ясування основної сфери зацікавленості автора провокує те, що і вертикальна, і горизональна траєкторії його погляду, його осяжність створили панорамність, а авторський погляд почав шукати глибину, адже «поверхня» людини й оточуючого середовища мінливі, осмислити їх можна, лише поринувши у «внутрішнє», «невидиме», сконцентрувавшись на сутності. Тому авторський погляд обирає в своїй горизонтальній траєкторії одну точку і починає приглядатися до неї. Панас Мирний так окреслює час: «В неділю, після раннього обіднього часу, тим шляхом, що, звившись гадюкою, послався од великого села Пісок аж до славного колись Ромодану, йшов молодий чоловік» (Мирний, 1968: 2).

Природа антропоморфна, вона виступає ліричною паралеллю до настроїв героїв, внутрішньо відповідає їх переживанням. Підтвердженням цього $є$ картина дощу, коли Чіпка йшов на каторгу: «Сонце заздалегоди, почувши іiі, надолужало своїм теплом: не гріло, а пекло. Дощ, як затявся, i трохи не на корх лежало на шляху пилу, та стояв він і у воздусі (повітрі), як сивий туман, ліз у вічі, душив у горлі» (Мирний, 1968: 102). У цьому пейзажі надзвичайно велика гострота зорового сприйняття навколишнього світу: Панас Мирний бачить пил і сонце, їх просторове положення.

Надзвичайно збільшується сприйняття, коли в просторі пейзажу з'являються люди: «У той час Грицько вертався 3 поля зі снопами, аж трьома возами. Він - за одним, Христя - за другим; а син хрещеник Галин - сидів на третім поверх снопів, тільки головка манячила» (Мирний, 1968: 253). 
Хронотоп поля в творчості Панаса Мирного відіграє важливу роль. Поле в українській традиції $\epsilon$ особливим простором, пов'язаним із ментальністю української людини. В українській культурі і літературі вже сформувалися особливі традиції зображення поля як простору специфічно українського, який символізує двоїстість, суперечливість української душі, і в той же час прийдешнього як незбагненного, ірраціонального, опинившись всередині якого людина просто втрачається, а подивившись на цей простір «зі сторони», мріє про нього, як про недосяжне: «Поле, що безкрає море, скільки зглянеш - розіслало зелений килим, аж сміється в очах», «Поле його годує, поле його втішає, на полі він виростає, на полі часом і вмирає. Поле - що воздух (повітря): нічим би дихати, якби зостався без його!» (Мирний, 1968: 2).

Організація роману Панаса Мирного характеризується тим, що сюжето-створюючі ситуації випробування розкривають неадекватність духовного потенціалу Чіпки та його вчинків. На це впливають тенденції сучасного йому життя, які його обмежують: у сфері історичного теперішнього Чіпка обмежений і як діяч, і як носій певної ідеологічної позиції.

Сучасна Панасу Мирному людина розкривається як суб'єкт філософсько-художнього дослідження людського життя під знаком Вічності. Таким чином встановлюється рівноправність соціальної та природної основ життя, рівноправність їх останніх позицій. Вказаний спосіб зображення дозволяє Панасу Мирному поєднувати сюжетну завершеність героя 3 його духовною незавершеністю, утвердження правди сьогоднішнього дня, повсякденності та їх перемоги над героєм із затвердженням правди героя.

Ідея пошуку правди вступає у конфлікт із часом, якого герой не здолав. Так змальовуєтся трагедія змарнованих років, усього життя. Трагедія людей, які не мають змоги використати усі свої можливості з вини суспільства, трагедія тих, хто 3 власної вини губить своє життя і життя людей, які могли б зробити їх щасливими. Чіпка Варениченко не зміг подолати власні амбіції, внаслідок чого зруйнував не тільки своє життя, а й життя близьких людей. Головний герой роману «Хіба ревуть воли, як ясла повні?» був впевнений, що сум в атмосфері злоби, алкогольних напоїв йому якось допоможе, проте цим він лише збагатив кмітливих людей, які скористалися станом героя. Такі обставини сприяли тому, що герой втратив головне у своєму житті - право на добросовісну працю, що й спричинило таку деградацію особистості. Чіпка втратив віру в те, що у житті можна всього досягнути чесним шляхом.

Розвінчення уявлення про щастя як накопичення чесним, а найчастіше нечесним шляхом багатства - одна 3 наскрізних тем реалістичної літератури. Боротьба за чесність, справедливість, спроби знайти правду в деморалізованому суспільстві стали наскрізним мотивом художнього методу Панаса Мирного. Письменник розумів, що саме правдивість повинна бути законом життя, нормою поведінки чесної людини, мірилом у підході і ставленні до людей. У понятті часу твору письменник розкриває злочинність і химерність гоніння за багатством, здобуття грошей заради наживи, незважаючи на скалічені життя інших, тому проблема часу постає як наскрізна соціальна і морально-етична проблема.

Проблема простору і часу не була для письменника самоціллю, проте саме вона становить частину найважливішої проблеми творчості письменника - визначення історичного шляху нації, типовим представником якої є головний герой роману Панаса Мирного «Хіба ревуть воли як ясла повні?». Письменника цікавить життя окремої людини у взаємозв'язку з історичним часом як частина цього часу, і як фактор, що створює цей час.

Висновки. Новий час диктує нові думки щодо тлумачення того, що саме хотів передати майбутньому поколінню письменник. Розгляд просторово-часової організації в романі Панаса Мирного «Хіба ревуть воли, як ясла повні?»є особливо важливим 3 огляду на індивідуальний творчий метод письменника. Вивчення категорій художнього часу й простору у творчості Панаса Мирного не втрачає своєї актуальності. Просторово-часова концепція, закладена у його романах, здатна стати ключем до розкриття картини світу письменника, дати уявлення про його світовідчуття.

\section{СПИСОК ВИКОРИСТАНИХ ДЖЕРЕЛ}

1. Мирний П. Зібрання творів: у 7 т. К. : Наукова думка, 1968. Т. 2. 1971. 393 с.

2. Лотман Ю. К проблеме пространственной семиотики. Семиотика пространства и пространства семиотики. Труды по знаковым системам. Т. : Александра, 1992. 472 с.

3. Бахтин М. Формы времени и хронотопа в романе. Очерки исторической поэтики. Вопросы литературы и эстетики. М. : Художественная литература, 1975. С. 234-407. 


\section{REFERENCES}

1. Mirnij P. Zibrannya tvoriv: U 7 t. [Collection of works: in 7 v.]. K. : Naukova dumka, 1968. T. 2. 1971, p. 393 [in Ukraine].

2. Lotman Y. K probleme prostranstvennoj semiotiki. Semiotika prostranstva i prostranstva semiotiki. Trudy po znakovym sistemam. [On the problem of spatial semiotics. Semiotics of space and space of semiotics. Proceedings on sign systems]. T. : Aleksandra, 1992, p. 472 [in Russian].

3. Bahtin M. Formy vremeni i hronotopa v romane. Ocherki istoricheskoj poetiki. Voprosy literatury i estetiki [Forms of time and chronotope in the novel. Essays on Historical Poetics. Literature and aesthetics]. M. : Fiction, 1975, p. 234-407 [in Russian]. 